\title{
KILKA UWAG O BLĘDACH W DWUSTRONNYCH UMOWACH POLSKO-ROSYJSKICH
}

\author{
Swietlana GAŚ, dr \\ Uniwersytet im. A. Mickiewicza w Poznaniu \\ Instytut Językoznawstwa \\ al. Niepodległości 4 \\ 61-874 Poznań, Poland \\ svetlanagas@gmail.com
}

\begin{abstract}
Abstrakt: Celem niniejszego artykułu jest wskazanie najczęstszych błędów w umowach międzynarodowych. Podstawę materiałową stanowią umowy podpisane pomiędzy Rzecząpospolitą Polską a Federacją Rosyjską. Choć w umowach międzypaństwowych błędy i pomyłki są niedopuszczalne, to występują $\mathrm{w}$ analizowanym materiale. Przyczyny powstawania błędów są przeważnie pozajęzykowe - psychologiczne lub fizjologiczne. Jednak czasem duża liczba błędów może świadczyć o niedostatecznej znajomości języka, braku umiejętności redagowania tekstów. $\mathrm{W}$ analizowanych tekstach zdarzają się pominięcia fragmentów lub nadmiar informacji, różnego typu błędy w nazwach umów międzynarodowych, niekonsekwentne użycie terminów w obrębie tego samego dokumentu, błędy ortograficzne. Część błędów występuje w wyrazach lub połączeniach wyrazowych o frekwencji względnie wysokiej. Wyodrębnione problemy językowe warto uwzględnić w kursach doskonalenia zawodowego, przy opracowywaniu programów oraz doborze materiałów dydaktycznych. Ponadto ważne jest krytyczne podejście do źródeł leksykograficznych i do własnych kompetencji.
\end{abstract}

Słowa kluczowe: kategorie błędów, język dyplomatyczny, umowy dwustronne

Abstract: The aim of this paper is to demonstrate the most frequent errors and mistakes in official international documents. The analysis is based on a collection of agreements between the Republic of Poland and Russian Federation. Errors and mistakes in diplomatic agreements are not acceptable, however, some examples of these are presented in the analysed corpora. The underlying causes of errors are mostly of non-linguistic character - they are mainly psychological or physiological. A large number of errors may indicate low-level language skills or translator's lack of knowledge about text editing rules. Omissions, excessive information, different kinds of errors in the titles of international agreements, inconsistent terms used within the same document or misspellings can be found in this corpora. A part of errors occurs in high-frequent words or collocations. It is suggested that these language problems are worth taking into consideration when planning vocational training courses or constructing syllabi and didactic materials. The importance of critical approach to lexicographic sources and own language skills has also been highlighted.

Key words: error types, diplomatic language, bilateral agreements 


\section{Uwagi wstępne}

Licząca już kilka dziesięcioleci teoria analizy błędów, w tym analiza kontrastywna, zajmuje ważne miejsce w nauce o języku i przede wszystkim ma charakter praktyczny. Powstały różne lingwistyczne szkoły lapsologiczne, rozwijają się kierunki teorii analizy błędów (glottodydaktyczny, translacyjny, lingwistyczny itp.), tworzą się słowniki błędów. Uwagę lingwistów przykuwają przeważnie błędy systemowe, typowe dla określonej grupy nadawców. Błędy, które powstają w wyniku przemęczenia, braku należytej uwagi, stresu, pod presją czasu, często są jednostkowe i nieprzewidywalne, dlatego też rzadziej znajdują się w centrum zainteresowań lingwistów kontrastywnych. Przyczyny błędów, występujących w dokumentach dyplomatycznych, są często pozajęzykowe, psychologiczne lub fizjologiczne, choć nie można wykluczyć, że mamy do czynienia z błędami systemowymi, wynikającymi z niedostatecznego opanowania języka. Słusznym wydaje się optymistyczne założenie, iż osoby odpowiedzialne za językową warstwę międzynarodowych umów są specjalistami, doskonale znającymi zasady redagowania i adiustacji tekstów, i kompetentnymi użytkownikami języka. Zdarzają się jednak błędy wynikające z niedostatecznej znajomości języka rodzimego. Celem tego artykułu jest wskazanie najczęstszych kategorii błędów w polsko-rosyjskich umowach dwustronnych, które można uwzględnić przy redagowaniu oficjalnych dokumentów, aby zminimalizować błędy i pomyłki w przyszłości ${ }^{1}$.

\section{Baza materiałowa}

Bazę materiałową do niniejszych badań stanowią umowy dwustronne pomiędzy Rzecząpospolitą Polską a Federacją Rosyjską. Wszystkie teksty pochodzą z Internetowej Bazy Traktatowej www.traktat.msz.gov.pl. Na stronie tej można przeczytać: „Internetowa Baza Traktatowa MSZ (zwana dalej IBT) zawiera wykazy i teksty umów międzynarodowych, których Polska jest lub była stroną. Są to umowy obowiązujące oraz te, które swoją moc obowiązującą już utraciły. IBT zawiera także umowy, którymi Polska zamierza się związać (tj. umowy jeszcze nieobowiązujące, ale w stosunku do których rozpoczęto krajową procedurę traktatową). Zamieszczenie w IBT umów międzynarodowych nie stanowi ich publikacji w rozumieniu ustawy z dnia 14 kwietnia 2000 r. o umowach międzynarodowych (Dz. U. z 2000 r. Nr 39, poz. 443 oraz z 2002 r. Nr 216, poz. 1824) i pełni wyłącznie rolę informacyjną i pomocniczą". Baza zawiera m.in. zeskanowane umowy polsko-rosyjskie, w tym również 89 umów obowiązujących (stan na lipiec 2014). Teksty umów w formacie .pdf są zamieszczone w jednej z poniższych wersji:

1 Por. „Analiza błędów w tłumaczeniach umożliwia przewidywanie błędów, a więc może (i powinna) stanowić podstawę opracowywania metod zapobiegania im, co jest jednym z najważniejszych zadań dydaktyki translacyjnej. Wyniki tych analiz należałoby uwzględnić w opracowywaniu (doborze) materiałów dydaktycznych (tekstów i ćwiczeń). Na ich podstawie można opracować (bądź uzupełnić) listy problemów językowych i tłumaczeniowych, które powinny być uwzględnione w programach nauczania tłumaczenia pisemnego" (Kozłowska 2002, 137). 
Swietłana GAŚ, Kilka uwag błędnych w dwustronnych umowach...

(i) dokumenty prawdopodobnie w dniu podpisania (o czym świadczą np. poprawki dokonane ręcznie),

(ii) teksty opublikowane w Dzienniku Ustaw lub Monitorze Polskim.

Niektóre z tych tekstów są tłumaczeniami albo z języka rosyjskiego na język polski, albo z języka polskiego na język rosyjski (np. noty dyplomatyczne). W przypadku innych dokumentów nie można stwierdzić jednoznacznie, czy dane teksty są tłumaczeniami, czy równolegle powstającymi wersjami językowymi. W 2009 roku Ministerstwo Spraw Zagranicznych sporządziło zalecenia dotyczące zawierania umów międzynarodowych, z których wynika, że przy opracowywaniu projektów umów należy kierować się rosyjską praktyką ${ }^{2}$.

W niniejszym artykule przeanalizowano umowy udostępnione na stronie www.traktat.msz.gov.pl wyłącznie w zamieszczonej tam wersji językowej. Nie uwzględniono zatem ewentualnych późniejszych sprostowań i poprawek w Dzienniku Ustaw lub w Monitorze Polskim. Łącznie korpus tekstowy dla celów niniejszej pracy zawiera 56 umów dwustronnych.

\section{Klasyfikacje błędów}

Błędy językowe są ,zjawiskiem naturalnym”, „nie można bowiem nigdy osiągnąć takiego stanu w zakresie przyswojenia jakiegoś zasobu wiedzy lub umiejętności, który by wykluczał w sposób absolutny popełnienie błędu" (Grucza 1978, 9). Mimo to w oficjalnych dokumentach międzynarodowych błędy są niedopuszczalne.

Dotychczas powstało wiele różnorodnych klasyfikacji błędów językowych i tłumaczeniowych ${ }^{3}$. Część $z$ tych klasyfikacji została poddana krytycznej analizie w późniejszych pracach językoznawczych (np. Kubacki 2012, Nowak 2006). F. Grucza na przykład odróżnia błędy sensu stricto („kategorie błędów popełnionych na skutek nieopanowania lub niedostatecznego opanowania danego języka") i błędy sensu largo, tj. pomyłki językowe („,kategorie błędów popełnionych lub popełnianych przez kompetentnych użytkowników danego języka, a więc takich, którzy są w stanie owe błędy skorygować") ${ }^{4}$ (Grucza 1978, 13). A.D. Kubacki w swojej monografii przytacza również klasyfikację błędów językowych Ch. Nord, która wyróżnia m.in. błędy leksykalne,

2 «При подготовке проекта договора следует руководствоваться прежде всего российской договорной практикой. В качестве примера рекомендуется использовать договоры, опубликованные в Собрании законодательства Российской Федерации и Бюллетене международных договоров, размещенные на интернет-сайтах федеральных органов власти, в авторитетных информационно-правовых базах» (http://www.mid.ru/bdomp/nsdp.nsf/0/C99D6BFE48CC8C67C32575930025E0FD).

3 Por. podział na błędy językowe i tłumaczeniowe w pracy Współczesne tendencje przekładoznawcze (Pisarska 1998, 158).

4 Por. klasyfikację C. Jamesa: „The clearest and most practical classification of deviance is a four-way one: i) slips..ii) mistakes... iii) errors... iv) solecisms" (James 1998, 83). 
syntaktyczne, gramatyczne, stylistyczne oraz trzy rodzaje błędów tłumaczeniowych (Kubacki 2012, 207). Inną klasyfikację błędów tłumaczeniowych przedstawiła H. Dzierżanowska. Badaczka wyodrębniła 5 kategorii podstawowych i 12 subkategorii błędów: 1) ortografia (pisownia i interpunkcja), 2) błędy gramatyczne (,formy i konstrukcje gramatyczne”), 3) szyk wyrazów (,zdanie i grupa wyrazowa”), 4) błędy leksykalne (,wyraz i grupa wyrazowa”), 5) adekwatność (sytuacyjna, stylistyczna, semantyczna) (Dzierżanowska 1990, 77). Choć ta typologia została opracowana ,specjalnie pod kątem widzenia przekładu z polskiego na angielski" (Dzierżanowska 1990, 77), można ją z powodzeniem stosować dla różnych par językowych.

$\mathrm{Na}$ podstawie analizowanego materiału nie można jednoznacznie stwierdzić, na którym etapie prac nad polskimi i rosyjskimi wersjami językowymi umów dwustronnych doszło do popełnienia błędów. Pomimo tego, klasyfikacja H. Dzierżanowskiej pozwala przeprowadzić w miarę przejrzystą analizę błędów. Zatem błędy odnotowane w polskorosyjskich umowach dwustronnych można podzielić na następujące kategorie: (i) nieadekwatność semantyczna, (ii) błędy leksykalne, (iii) błędy ortograficzne, (iv) błędy gramatyczne.

\section{Błędy w dwustronnych umowach}

\section{Nieadekwatność semantyczna}

Pod nieadekwatnością semantyczną H. Dzierżanowska rozumie opuszczenia, „wypaczenia sensu oraz błędy w przenoszeniu np. danych liczbowych, nazw miejscowości itp." (Dzierżanowska 1990, 101). W analizowanym korpusie tekstowym występują pominięcia fragmentu oraz nadmiar lub niedostateczna ilość informacji ${ }^{5}$.

\section{Przykład nr 1}

„Umawiające się strony będą sprzyjać współpracy i różnorodnym formom kontaktów między młodzieżą i organizacjami młodzieżowymi obu krajów, jak również przedstawicielami instytucji pracujących z młodzieżą." - «Стороны будут способствовать разнообразным формам контактов между молодежью и молодежными организациями обеих стран, а также представителями учреждений, ведущих работу с молодежью» (2) (brak rzeczownika сотрудничество 'współpraca' w wersji rosyjskiej)

\section{$\underline{\text { Przykład nr } 2}$}

„Na podstawie odrębnych ustaleń między Stronami inni dawcy międzynarodowi także mogą udzielać wsparcia zgodnie z celami niniejszej umowy poprzez program wspierania Strony Polskiej”. - «На основе отдельных договоренностей между Сторонами другие доноры могут оказывать содействие в соответствии с целями настоящего Соглашения через программу содействия Польской Стороны». (8) (przymiotnik międzynarodowy w wersji polskiej)

\footnotetext{
${ }^{5}$ Więcej zob. (Pisarska 1998, 162-163).
} 
Swietłana GAŚ, Kilka uwag błędnych w dwustronnych umowach...

Połączenie leksykalne dawca międzynarodowy jest dość nietypowe. Wydaje się, że pominięcie przymiotnika lub zastąpienie go innym przymiotnikiem jest lepszym rozwiązaniem.

\section{Przykład nr 3}

„Umawiające się Strony będą sprzyjać wymianie informacji dotyczących młodzieży...” «Стороны будут способствовать эффективному обмену информацией, касающейся молодежи...» (2) (przymiotnik эффективныій w wersji rosyjskiej)

Warto zaznaczyć, że użycie przymiotnika эффективный zasadniczo nie wnosi istotnej informacji. Jednak ogólnie w dyskursie dyplomatycznym, zwłaszcza w wypowiedziach dyplomatów lub oświadczeniach rzecznika prasowego MSZ, takiego typu kolokacje mają funkcje pragmalingwistyczne.

\section{$\underline{\text { Przykład nr } 4}$}

„Do realizacji postanowień niniejszej Umowy tworzy się Komisje mieszana do spraw współpracy w dziedzinie polityki antymonopolowej i ochrony praw konsumenckich”. «Для реализации настоящего Соглашения создается смешанная Комиссия по сотрудничеству в области антимонопольной политики, развития конкуренции и защиты прав потребителей». (9) (brak połączenia leksykalnego rozwój konkurencji w wersji polskiej)

\section{Błędy leksykalne}

W analizowanym materiale zaskakujące jest to, że błędy występują również w nazwach ważnych dokumentów, jak na przykład Traktat o przyjaznej i dobrosąsiedzkiej współpraсу - Договор о дружественном и добрососедском сотрудничестве . $^{6}$

6 Polskie i rosyjskie nazwy podstawowych dokumentów dyplomatycznych zawiera Podręczny idiomatykon polsko-rosyjski (Chlebda 2007). Choć również autorom tego niezwykłego opracowania leksykograficznego zdarzają się pomyłki, np. Umowa między Rządem Rzeczypospolitej Polskiej a Rządem Federacji Rosyjskiej o wspólpracy w dziedzinie kultury, nauki i oświaty (1993) to nie: Декларация о сотрудничестве в области культуры, науки и образования между Правительством Российской Федераџии и Правительством Республики Польша (ponieważ jest to inny dokument, mianowicie Deklaracja o współpracy kulturowej, naukowej i oświatowej między Rządem Rzeczypospolitej Polskiej a Rzadem Federacji Rosyjskiej z dnia 22 maja 1992 r.), a dokument pt. Соглашение между Правительством Республики Польша и Правительством Российской Федераиии о сотрудничестве в области культуры, науки и образования. Należу zauważyć, że redaktorzy i autorzy wydań idiomatykonu szczególnie dbają o kwestie poprawnościowe i zamieszczają corrigendy. Warto jednak zalecać przyszłym thumaczom krytyczne podejście do słowników. 


\section{$\underline{\text { Przykład nr } 5}$}

„...działając zgodnie z Umowa między Rzeczapospolita Polska i Federacją Rosyjską o przyjaznej i dobrosąsiedzkiej współpracy...” - «...действуя в соответствии с Договором между Республикой Польша и Российской Федерацией о дружественном и добрососедском сотрудничестве...» (9) (użycie leksemu umowa zamiast traktat)

\section{$\underline{\text { Przykład nr } 6}$}

„,...kierując się postanowieniami Traktatu między Rzeczapospolita Polska a Federacja Rosyjska o przyjaznej i dobrosasiedzkiej współpracy...” - «...руководствуясь положениями Договора между Республикой Польша и Российской Федерацией о дружественном, добрососедском сотрудничестве...» (10) (brak spójnika $u$, zamiast spójnika przecinek)

\section{Przykład nr 7}

„Arbitraż będzie się składać z trzech arbitrów. Każda Strona wyznacza po jednym arbitrze, którzy zgodnie wybierają Przewodniczącego, przy czym na Przewodniczącego może być wybrany wyłącznie obywatel lub poddany strony trzeciej”. - «Арбитраж будет состоять из трех арбитров. Каждая Сторона назначает по одному арбитру, которые на основе взаимного согласия избирают Председателя арбитража, при этом Председателем может быть избран только гражданин или подданный третьей страны» (11) (brak ekwiwalencji strona trzecia - третья страна 'trzeci kraj', lepiej: третье государство - państwo trzecie)

\section{$\underline{\text { Przykład nr } 8}$}

„...kierując się pragnieniem dalszego rozwoju przyjacielskich stosunków między obydwoma Państwami..." - «...руководствуясь желанием дальнейшего развития дружественных отношений...» (12) (użycie przymiotnika przyjacielski zamiast przyjazny)

\section{$\underline{\text { Przykład nr } 9}$}

„Strony będą popierać rozwój wymiany turystycznej w celu wzajemnego zapoznania się z kulturą i nauką obu krajów”. - «Стороны будут содействовать развитию туристических обменов с целью взаимного ознакомления с культурой и наукой обеих стран». (7)

„Umawiające się Strony będą dążyć do uproszczenia granicznych, celnych i innych formalności związanych z wymianą turystyczną między Rzecząpospolitą Polską a Federacją Rosyjską". - «Стороны будут стремиться к упрощению пограничных, таможенных и иных формальностей, связанных с туристским обменом между Республикой Польша и Российской Федерацией». (10) 
Swietłana GAŚ, Kilka uwag błędnych w dwustronnych umowach...

Problemy dotyczące użycia przymiotników туристический, туристский próbują rozstrzygnąć lingwiści normatywni współpracujący z portalem www.gramota.ru. Według nich przymiotnik туристский ma znaczenie 'dotyczący turystów', zaś przymiotnik туристический - 'dotyczący turystyki'. Nie zawsze to rozróżnienie jest istotne. Ponadto nasila się tendencja używania przymiotnika туристический․

\section{Przykład nr 10}

„...tworzenia w swoich krajach warunków do współpracy gospodarczej i incestycyjnej" - «...создания условий для развития хозяйственного и инвестиционного сотрудничества и совместного предпринимательства» (9) (lepiej: współpraca gospodarсzа - экономическое сотрудничество)

„W rozwijaniu stosunków polsko-rosyjskich Strony przywiązują duże znaczenie do bezpośrednich związków oraz współpracy gospodarczej i społeczno-kulturalnej północno-wschodnich województw Rzeczypospolitej Polskiej i Obwodu Kaliningraddzkiego Federacji Rosyjskiej”. - «В развитии польско-российских отношений Стороны придают большое значение непосредственным связям, а также хозяйственному и социально-культурному сотрудничеству северо-восточных воеводств Республики Польша и Калининградской области Российской Федерации» (3) (lepiej: экономические сотрудничество, zob. dane językowe na www.ruscorpora.ru)

\section{Przykład nr 11}

„...dążąc do pogłębiania i doskonalenia wzajemnej współpracy...” - «...стремясь к углублению и совершенствованию взаимного сотрудничества в области правовой помощи и правовых отношений» (5) (poprawnie: współpracy сотрудничества)

7 Poradnia językowa Spravka tak wyjaśnia swoją decyzję: „Прилагательное туристский образовано непосредственно от слова турист и имеет значение 'относящийся к туристу (туристам)': туристская палатка, туристский лагерь, туристские ботинки. Прилагательное туристический связано по смыслу в первую очередь с существительным туризм и значит 'относящийся к туризму': туристическое бюро, туристическая виза, туристическая поездка, туристические буклеты. Это различие не всегда существенно. Так, марирут можно назвать и туристским, и туристическим, базу - и туристской, и туристической. Но, например, говоря о фирме, организации используют только слово туристический: туристическая фирма, туристическая компания. В значении 'группа туристов' - только туристская компания. Прилагательное туристский используется в Федеральном законе «Об основах туристской деятельности в Российской Федерации» в следующих сочетаниях: туристская деятельность, туристские ресурсы, туристская индустрия, туристский продукт, туристская путевка.Заметим, что в слове туристский наблюдается стечение четырех согласных стск, что делает это прилагательное неудобным для произнотения. Этим, видимо, и объясняется большая популярность слова туристический как «замены» туристскому"

http://www.gramota.ru/spravka/trudnosti/36_193 (14.11.2014). 
Językoznawcy normatywni podkreślają, że kolokacja wzajemna współpraca — взаимное сотрудничество jest niepoprawna, ale nadal ta kolokacja występuje dość często (Markowski 2004).

\section{$\underline{\text { Przykład nr } 12}$}

„W sprawach opieki i kurateli właściwe jest... prawo tej Umawiającej się Strony, której obywatelem jest osoba potrzebująca opiekuna lub kurateli" «В вопросах опеки и попечительства применяется ... законодательство Договаривающейся Стороны, гражданином которой является $\underline{\text { лицо, }}$ нуждающееся в опеке и попечительстве».

„W sprawach ustanowienia opieki i kurateli właściwy jest organ tej Umawiającej się Strony, której obywatelem jest osoba potrzebujaca opieki lub kurateli” - «По делам об установлении опеки и попечительства компетенен орган Договаривающейся Стороны, гражданином которой является лицо, нуждающееся в опеке или попечительстве» (5) (brak konsekwencji użycia jednego terminu w obrębie jednego tekstu)

\section{$\underline{\text { Przykład nr } 13}$}

„Przedstawiciele krajów trzecich lub organizacji międzynarodowych, mogą być włączani do udziału w pracach wynikających z porozumień, umów i kontraktów realizowanych w ramach niniejszego Porozumienia." - «Представители организаций третьих государств или международных организаций могут приглашаться для участия в реализации соглашений, договоров и контрактов, выполняемых в рамках настоящего Соглашения» (4) (lepiej: państwa trzecie, ponadto w wersji rosyjskiej występuje dodatkowy rzeczownik организаиий, błąd interpunkcyjny w wersji polskiej)

Termin państwa trzecie występuje w Leksykonie dyplomatycznym. Definiując to ważne pojęcie, J. Sutor ani razu nie stosuje rzeczownika kraj (Sutor 2005). Zaleca się, aby w dokumentach międzynarodowych konsekwentnie stosowano leksem państwo.

\section{Błędy ortograficzne}

W umowach dwustronnych występują zarówno tzw. literówki, jak i błędy w pisowni wielkich i małych liter. Odrębną grupę stanowią błędy interpunkcyjne. Niewątpliwie, żadne $\mathrm{z}$ tych odstępstw od zasad poprawnościowych nie jest dopuszczalne.

8 „Państwa trzecie - termin stosowany w umowach i organizacjach międzynarodowych, oznaczający, że dane państwo nie jest stroną traktatu lub organizacji międzynarodowej. Państwa te korzystają jednak $\mathrm{z}$ określonych prerogatyw wypływających $\mathrm{z}$ umów przewidujących określone korzyści na rzecz państw trzecich lub też w przypadku organizacji międzynarodowych - z możliwości akredytowania obserwatora korzystającego z określonych przywilejów i immunitetów oraz pewnych uprawnień w ramach samej organizacji” (Sutor 2005, 270). Por. definicje terminów państwo buforowe, państwo przyjmujace, państwo śródlądowe, państwo wysyłające (Sutor 2007, 271). 
Swietłana GAŚ, Kilka uwag błędnych w dwustronnych umowach...

\section{$\underline{\text { Przykład nr } 14}$}

„... z własnej inicjatywy” - «... по собственной иницнативе» (1) (litera $н$ zamiast $u$, poprawnie: инициативе)

Zasady użycia wielkich i małych liter w umowach często stwarzają problemy thumaczom i redaktorom. W regularnie uaktualnianym poradniku Справочник по оформлению нормативных правовых документов pisowni wielkich i małych liter poświęcono duży rozdział ${ }^{9}$. Zgodnie z zaleceniami autorów tego poradnika w umowach międzynarodowych, porozumieniach i konwencjach dużą literą należy pisać następujące wyrazy i połączenia wyrazowe: Договор, Конвенция, Соглашение, Сторона, Стороны, Высокие Договариваюшиеся Стороны, Договариваюшиеся Стороны, Российская Сторона, Итальянская Сторона, Узбекистанская Сторона. Те próby ujednolicenia dokumentów są uzasadnione, jeżeli wziąć pod uwagę dowolność w zapisie ww. zwrotów w rosyjskich wersjach umów międzynarodowych.

\section{$\underline{\text { Przykład nr } 15}$}

„,...po Stronie polskiej - Generalna Dyrekcja Dróg Krajowych i Autostrad Rzeczypospolitej Polskiej" - «...c Польской Стороны - Генеральная Дирекция внутренних дорог и автострад Республики Польша»;

„po Stronie rosyjskiej - Ministerstwo Transportu Federacji Rosyjskiej” - «c Российской Стороны - Министерство транспорта Российской Федерации» „... po Stronie polskiej - Wojewoda Warmińsko-Mazurski;

po Stronie rosyjskiej - Państwowy Komitet Celny Federacji Rosyjskiej" - «...c Польской стороны - Варминьско-Мазурский воевода;

с Российской стороны - Государственный таможенный комитет Российской Федерации» (6) (dwa warianty pisowni w obrębie jednego artykułu)

\section{$\underline{\text { Przykład nr } 16}$}

„Rząd Rzeczypospolitej Polskiej i Rząd Federacji Rosyjskiej zwane dalej umawiającymi się Stronami...” - «Правительство Республики Польша и Правительство Российской Федерации, далее именуемые сторонами...» (2)

W omawianych tekstach błędy interpunkcyjne są zjawiskiem rzadkim.

\section{$\underline{\text { Przykład nr } 17}$}

„kwestie zwiazane z przedmiotem...”"«... по вопросам имеющим отношение к предмету...» (1) (brak przecinka po wyrazie вопросам)

9 Zob. Справочник по оформлению нормативных правовых документов в Администрации Президента Российской Федерации (по состоянию на 1 июля 2012),

htttp://www/garant/ru/produtcs/ipo/prime/doc/70111106/?prime (dostęp 5.07.2014) 


\section{$\underline{\text { Przykład nr } 18}$}

„...podmioty prowadzące działalność gospodarczą...” - «...субъектами занимающимися хозяйственной деятельностю...» (1) (brak przecinków po wyrazach субъектами, деятельностью, ponadto brak litery $b \mathrm{w}$ rzeczowniku деятельностью)

\section{Błędy gramatyczne}

Błędy gramatyczne powstają albo w wyniku poprawek dokonanych ręcznie (np. zmienia się rekcja, liczba itd.), albo ze względu na niestaranną adiustację i redagowanie ostatecznej wersji dokumentu.

\section{$\underline{\text { Przykład nr } 19}$}

„Informacje wymienione w ustępie 1 niniejszego Artykułu są udzielane...” «Информация, предусмотрена пункте 1 настоящей статии, предоставляется...»

(1) (предусмотрена zamiast предусмотренная, статии zamiast статьи)

\section{Wnioski}

Przeprowadzona analiza normatywna dwustronnych umów polsko-rosyjskich pozwala stwierdzić, że nawet w dokumentach dyplomatycznych błędy oraz pomyłki nie są zjawiskiem rzadkim. Etiologia tych błędów nie jest jasna. Można przypuszczać, że część odstępstw od norm językowych i reguł ortograficznych wynika z przyczyn psychologicznych lub fizjologicznych (przemęczenie, stres, presja czasu, złe samopoczucie) oraz z przyczyn organizacyjnych (niedostateczna liczba osób odpowiedzialnych za językową warstwę tekstów). Duża liczba błędów w niektórych tekstach zmusza do zastanowienia się nad kompetencjami językowymi niektórych wykonawców.

Większość błędów stanowią błędy leksykalne (w tym błędy terminologiczne), ortograficzne i gramatyczne. Zauważono, że część błędów występuje w wyrazach lub połączeniach wyrazowych o frekwencji względnie wysokiej (np. pisownia dużą lub małą literą, nazwy podstawowych dokumentów dyplomatycznych, typowe dla dyskursu dyplomatycznego kolokacje, np. przyjazne stosunki). Warto uwzględnić ten fakt w ewentualnych kursach doskonalenia zawodowego, w programach nauczania oraz ewentualnych materiałach dydaktycznych. Ważne jest krytyczne podejście do słowników, poradników i do własnych kompetencji. Być może należy rozważyć zwiększenie liczby osób redagujących teksty oraz wydłużenie czasu przeznaczonego na wykonanie tego odpowiedzialnego zadania. 
Swietłana GAŚ, Kilka uwag błędnych w dwustronnych umowach...

\section{Źródła cytowane}

Porozumienie między Generalnym Inspektorom Celnym Rzeczypospolitej Polskiej a Federalną Służbą Policji Podatkowej Federacji Rosyjskiej o współpracy w walce z przestępstwami w sferze działalności gospodarczej - Соглашение между Генеральным таможенным инспектором Республики Польша и Федеральной службой налоговой полиции Российской Федерации о сотрудничестве в борьбе с преступлениями в сфере экономической деятельности (1).

Porozumienie między Rządem Rzeczypospolitej Polskiej a Rządem Federacji Rosyjskiej o współpracy młodzieżowej - Соглашение между Правительством Республики Польша и Правительством Российской Федерации о молодежном сотрудничестве (1996) (2).

Porozumienie między Rządem Rzeczypospolitej Polskiej a Rządem Federacji Rosyjskiej o współpracy północno-wschodnich województw Rzeczypospolitej Polskiej i Obwodu Kaliningradzkiego Federacji Rosyjskiej - Соглашение между Правительством Республики Польша и Правительством Российской Федерации о сотрудничестве северо-восточных воеводств Республики Польша и Калининградской области Российской Федерации (3).

Porozumienie między Rządem Rzeczypospolitej Polskiej a Rządem Federacji Rosyjskiej o wspótpracy w dziedzinie nauki i techniki - Соглашение между Правительством Республики Польша и Правительством Российской Федерации о сотрудничестве в области науки и техники (1993) (4).

Umowa między Rzecząpospolitą Polską a Federacją Rosyjską o pomocy prawnej i stosunkach prawnych w sprawach cywilnych i karnych - Договор между Республикой Польша и Российской Федерацией о правовой помощи и правовых отношениях по гражданским и уголовным делам (1996) (5).

Umowa między Rządem Rzeczypospolitej Polskiej a Rządem Federacji Rosyjskiej o przebudowie dróg i budowie drogowych przejść granicznych dla zapewnienia komunikacji drogowej między Elblągiem (Rzeczypospolita Polska) i Kaliningradem (Federacja Rosyjska) - Договор между Правительством Республики Польша и Правительством Российской Федерации о реконструкции автомобильных дорог и строительстве на них автомобильных пунктов пропуска для обеспечения автомобильного сообщения между Эльблонгом (Республика Польша) и Калининградом (Российская Федерация) (2003) (6).

Umowa między Rządem Rzeczypospolitej Polskiej a Rządem Federacji Rosyjskiej o współpracy w dziedzinie kultury, nauki i oświaty (1993) - Соглашение между Правительством Республики Польша и Правительством Российской Федерации о сотрудничестве в области культуры, науки и образования (1993) (7).

Umowa między Rządem Rzeczypospolitej Polskiej a Rządem Federacji Rosyjskiej o wspólpracy w dziedzinie niszczenia broni chemicznej - Соглашение между Правительством Республики Польша и Правительством Российской Федерации о сотрудничестве в области уничтожения химического оружия (8).

Umowa między Rządem Rzeczypospolitej Polskiej a Rządem Federacji Rosyjskiej o wspótpracy w dziedzinie polityki antymonopolowej - Соглашение между Правите- 
льством Республики Польша и Правительством Российской Федерации о сотрудничестве в области антимонопольной политики (9).

Umowa między Rządem Rzeczypospolitej Polskiej a Rządem Federacji Rosyjskiej o współpracy w dziedzinie turystyki - Соглашение между Правительством Республики Польша и Правительством Российской Федерации о сотрудничестве в области туризма (2002) (10).

Umowa między Rządem Rzeczypospolitej Polskiej i Rządem Federacji Rosyjskiej o współpracy w dziedzinie zapobiegania awariom przemysłowym, klęskom żywiołowym i likwidacji ich skutków - Соглашение между Правительством Республики Польша и Правительством Российской Федерации о сотрудничестве в области предупреждения промышленных аварий, стихийных бедствий и ликвидации их последствий (1993) (11).

Umowa między Rzecząpospolitą Polską a Federacją Rosyjską o pomocy prawnej i stosunkach prawnych w sprawach cywilnych i karnych - Договор между Республикой Польша и Российской Федерацией о правовой помощи и правовых отношениях по гражданским и уголовным делам (1996) (12). 
Swietłana GAŚ, Kilka uwag błędnych w dwustronnych umowach...

\section{Bibliografia}

James, Carl. 1998. Errors in Language Learning and Use: exploring error analysis. London and New York: Longman.

Chlebda, Wojciech, red. 2007. Podręczny idiomatykon polsko-rosyjski. Opole: Wydawnictwo Uniwersytetu Opolskiego.

Dzierżanowska, Halina. 1990. Przekład tekstów literackich na przykładzie języka angielskiego. Warszawa: Państwowe Wydawnictwo Naukowe.

Grucza, Franciszek, red. 1978. Z problematyki błędów obcojęzycznych. Warszawa: Wydawnictwi Szkolne i Pedagogiczne.

Karczewska, Dorota. 2002. O błędach w tłumaczeniu. W Język rodzimy a język obcy: komunikacja, przekład, dydaktyka, red. Kopczyński Andrzej i Urszula ZaliwskaOkrutna, ss. 129-135. Warszawa: Wydawnictwo Uniwersytetu Warszawskiego.

Kozłowska, Zofia. 2002. O błędach językowych w tekstach polskich przekładów. W Język rodzimy a język obcy: komunikacja, przekład, dydaktyka, red. Kopczyński Andrzej i Urszula Zaliwska-Okrutna, ss. 137-147. Warszawa: Wydawnictwo Uniwersytetu Warszawskiego.

Kubacki, Artur. 2012. Tłumaczenie poświadczone. Status, kształcenie, warsztat i odpowiedzialność tłumacza przysięgłego. Warszawa: Wolters Kluwer.

Markowski, Andrzej, red. 2004. Wielki słownik poprawnej polszczyzny PWN. Warszawa: Wydawnictwo Naukowe PWN.

Nowak, Paulina. 2006. Analiza błędów w przekładzie unijnych aktów normatywnych na przykładzie Council Regulation (EC) no 1346/2000 of 29 May 2000 on Insolvency Proceedings. Investigationes Linguisticae nr XIII, ss. 171-195, http://www.inveling.amu.edu.pl//pdf/Paulina_Nowak_INVE13.pdf.

Sutor, Julian. 2005. Leksykon dyplomatyczny. Warszawa: Wydawnictwo Prawnicze LexisNexis.

Pisarska, Alicja, i Teresa Tomaszkiewicz. 1998. Współczesne tendencje przekładoznawcze. Poznań: UAM.

\section{Źródła internetowe}

http://www.gramota.ru/spravka/trudnosti/36 193 (dostęp 14.11.2014)

http://www.ruscorpora.ru

http://www.traktaty.msz.gov.pl

http://www.garant.ru/products/ipo/prime/doc/70111106/?prime (dostęp 5.07.2014)

http://www.mid.ru/bdomp/ns-dp.nsf/0/C99D6BFE48CC8C67C32575930025E0FD

(dostęp 14.04.2015) 
